\title{
Lewis Namier a kwestia ,,linii Curzona” i kształtowania się polskiej granicy wschodniej po I wojnie światowej ${ }^{1}$
}

Zarys treści: Artykuł dotyczy postaci Lewisa Namiera, eksperta do spraw polskich w Foreign Office, i jego związków z projektem „linii Curzona” - polsko-ukraińskiego rozgraniczenia w Galicji Wschodniej po I wojnie światowej. Pochodzący z Polski Namier, w czasie wojny i późniejszej konferencji pokojowej w Wersalu, konsekwentnie przeciwstawiał się roszczeniom polskim na wschodzie Europy, chcąc odciąć od niej całe terytorium Kresów Wschodnich. Jego koncepcje i działania wpisywały się w generalną linię polityki brytyjskiej w stosunku do Polski, aczkolwiek wydaje się, że nie był on szarą eminencją gabinetu Lloyda George’a w tej kwestii, będąc jedynie wygodnym dostarczycielem argumentów przeciwko roszczeniom polskim na wschodzie. Autor stara się również udowodnić, że ogromna rola, jaką przypisała Namierowi polska historiografia, jest przesadzona i to nie on był - jak się powszechnie uważa - faktycznym twórcą koncepcji „linii Curzona” i nie Namier umieścił ją w znanej nocie wysłanej ze Spa do bolszewików w lipcu 1920 r.

Słowa kluczowe: Lewis Namier, polska granica wschodnia, „linia Curzona”, Konferencja Wersalska, Galicja Wschodnia

Key words: Polish eastern border, „Curzon line”, Paris Peace Conference, Eastern Galicia

Odradzające się na nowo, po 123 latach niewoli, państwo polskie musiało zmierzyć się z niezliczoną ilością problemów, w tym z chaosem w naszej części Starego Kontynentu. Rewolucja rosyjska i późniejsza wojna domowa w Rosji, eksplozja separatyzmów narodowych na „okrainach” dawnego imperium i wynikające z nich konflikty między poszczególnymi narodami czy etnosami stanowiły nie lada wyzwanie dla ośrodków tworzących polską politykę zagraniczną. Powszechne było w tych

\footnotetext{
${ }^{1}$ Artykuł niniejszy stanowi rozszerzenie fragmentu pracy magisterskiej autora pt. „Dzieje koncepcji linii Curzona i kształtowania się polskiej granicy wschodniej w latach 1918-1945”, przygotowanej pod opieką prof. dr. hab. Grzegorza Mazura i obronionej w 2010 roku w Instytucie Nauk Politycznych i Stosunków Międzynarodowych Uniwersytetu Jagiellońskiego.
} 
kręgach dążenie do odzyskania większości ziem dawnej Rzeczypospolitej Obojga Narodów lub przynajmniej silniejsze związanie ich z państwem polskim² ${ }^{2}$.

Całą sprawę komplikowały dodatkowo mocarstwa zwycięskiej koalicji, tworzące własne koncepcje i plany ułożenia powojennych stosunków w Europie Środkowo-W schodniej, często, niestety, nie biorąc w ogóle pod uwagę woli mieszkającej na tych terenach ludności. Przedstawicielom wielkich mocarstw w podejmowaniu decyzji według własnego uznania nie przeszkadzała nawet bardzo znikoma wiedza na temat realiów i stosunków panujących w środkowo-wschodniej części Starego Kontynentu ${ }^{3}$. Często też zachodni politycy wykazywali postawę pełną chwiejności i niezdecydowania, zmieniając wcześniejsze postanowienia, przy czym jednym $z$ głównych motywów takiego postępowania było ponowne odrodzenie się wzajemnych antagonizmów wśród członków Ententy, szczególnie widoczne w stosunkach brytyjsko-francuskich. Efekt znamy: nietrwały ład międzynarodowy, utrzymujący się niewiele ponad dwadzieścia lat, zakończony wybuchem kolejnego światowego konfliktu 4 .

W podobny sposób starano się na Zachodzie rozwiązać problem wszystkich granic odrodzonej Rzeczypospolitej. Problematyka ta została już szczegółowo omówiona i opisana, ciągle jednak powstają nowe prace i przyczynki przynoszące zupełnie nowe ustalenia i szczegóły ${ }^{5}$. Artykuł niniejszy aspiruje do wypełnienia jednej z takich luk, a dotyczy on postaci Lewisa Namiera (1888-1960), eksperta w brytyjskim Foreign Office w czasie I wojny światowej i konferencji pokojowej w Paryżu. Jest to postać znana polskim historykom zajmującym się tym okresem, niemniej jednak poświę-

${ }^{2}$ Na temat koncepcji Józefa Piłsudskiego i Romana Dmowskiego istnieje ogromna literatura. Z nowszych prac można wskazać m.in. A. Nowak, Polska i trzy Rosje. Studium polityki wschodniej Józefa Piłsudskiego (do kwietnia 1920 roku), Kraków 2001; A. Czubiński, Walka Józefa Piłsudskiego o nowy kształt polityczny Europy Środkowo-Wschodniej w latach 1918-1921, Toruń 2002; Myśl polityczna Romana Dmowskiego, red. J. Engelgard, Warszawa 2009. Zob. także artykuły A. Nowaka (Geopolityczne koncepcje Józefa Piłsudskiego) oraz P. Korysia (Pomiędzy Rosją a Niemcami, czyli wizja geopolityczna Romana Dmowskiego) w książce: Przeklęte miejsce Europy? Dylematy polskiej geopolityki, red. J. Kloczkowski, Kraków 2009.

${ }^{3}$ Do legendy przeszła już ignorancja brytyjskiego premiera Davida Lloyda George’a, dyletanta w sprawach międzynarodowych. Tytułem przykładu można wskazać pomylenie przez niego prowincji hiszpańskiej o nazwie Galicja z Galicją Wschodnią na dawnych Kresach Rzeczypospolitej. Zob. J. Pisulińnki, Nie tylko Petlura. Kwestia ukraińska w polskiej polityce zagranicznej 1918-1923, Wrocław 2004, s. 75.

4 Pełny obraz dwudziestolecia międzywojennego rekonstruuje Henryk Batowski w swoim klasycznym już opracowaniu: Między dwiema wojnami 1919-1939. Zarys historii dyplomatycznej, Kraków 2001. W aneksie do tego wydania (II) jego pracy znajduje się również uaktualniona o nowe prace bibliografia (za lata 1985-2001), przygotowana przez J. J. Bruskiego. Zob. H. Batowski, Między dwiema wojnami..., s. 507-527.

${ }^{5} \mathrm{Na}$ ten temat szerzej zob. J. Karski, Wielkie mocarstwa wobec Polski 1919-1945. Od Wersalu do Jałty, Warszawa 1998; M. Nowak-Kiełbikowa, Polska - Wielka Brytania 1918-1923. Kształtowanie się stosunków politycznych, Warszawa 1975; J. Kukułka, Francja a Polska po traktacie Wersalskim (1919-1922), Warszawa 1970; M. Baumgart, Wielka Brytania a odbudowa Polski 1914-1923, Szczecin 1990; H. Batowski, Zachód wobec granic Polski. Niektóre fakty mniej znane, Łódź 1995; J. R. Wędrowski, Stany Zjednoczone a odrodzenie Polski. Polityka Stanów Zjednoczonych wobec sprawy polskiej i Polski w latach 1916-1919, Wrocław 1980; M. Leczyk, Komitet Narodowy Polski a Ententa i Stany Zjednoczone 1917-1919, Warszawa 1966. 
cono jej dotąd bardzo niewiele uwagi, co jest zupełnie niezrozumiałe w kontekście przypisywanych Namierowi ogromnych wpływów i znaczenia, jakie miał on rzekomo mieć przy wyznaczaniu kierunków polityki brytyjskiej w stosunku do państwa polskiego. To właśnie z jego nazwiskiem kojarzy się najczęściej koncepcję „linii Curzona”, brytyjskiego projektu rozgraniczenia między Polską a Rosją, odcinającego od niej całe terytorium Kresów Wschodnich ${ }^{6}$. O kształcie polskiej granicy zadecydował wtedy wynik wojny polsko-bolszewickiej z 1920 roku, który cały projekt brytyjski uczynił bezużytecznym. Problem w tym, że do owego pomysłu powrócono po raz kolejny po wybuchu II wojny światowej, m.in. w czasie debat Wielkiej Trójki nad ustaleniem powojennego porządku w Teheranie i Jałcie. Także wtedy sprawa „linii Curzona" wywołała pewne kontrowersje wśród obradujących, wykracza to jednak poza ramy przyjęte w niniejszym tekście ${ }^{7}$. Nas najbardziej interesować będzie znalezienie odpowiedzi na dwa zasadnicze pytania: jaka była rzeczywista rola Lewisa Namiera w kształtowaniu polityki zagranicznej Wielkiej Brytanii w stosunku do Polski i czy naprawdę był on twórcą „linii Curzona”? Wydaje się bowiem, że jego autorytet ani dokonania nie były aż tak wielkie, jak się powszechnie przyjmuje. Zanim jednak przejdziemy do zasadniczego problemu omawianego $\mathrm{w}$ artykule, należy przybliżyć sylwetkę głównego bohatera.

\section{Dzieciństwo i młodość Lewisa Namiera}

Lewis Namier urodził się w 1888 roku w Woli Okrzejskiej (na dzisiejszej Lubelszczyźnie) jako Ludwik Bernstein. Wtedy były to ziemie zaboru rosyjskiego. Wcześniej był to dom rodziny Cieciszowskich, tam też urodził się Henryk Sienkiewicz. Bernsteinowie wywodzili się z Winnicy na rosyjskiej Ukrainie. Pierwsza znana osoba $z$ tej rodziny zajmowała się produkcją sukna dla armii rosyjskiej, dostarczając jej w pewnym okresie aż $40 \%$ całego zapotrzebowania. Z czasem rodzina Bernsteinów zaczęła się asymilować z kulturą polską, a główny przełom $\mathrm{w}$ tym procesie nastąpił w czasie powstania styczniowego, w którym brał udział dziad Namiera, Jakub Chaim Bernstein. Ludwik opisał ojca Józefa w czarnych barwach jako nałogowego hazardzistę i utracjusza, co miało być zresztą przyczyną problemów finansowych w domu rodzinnym ${ }^{8}$.

\footnotetext{
${ }^{6}$ Szczegółowy przebieg „linii Curzona” (wymieniający ważniejsze miasta, między którymi miała ona przebiegać) znajduje się w nocie wysłanej 11 lipca 1920 roku ze Spa w Belgii. O dokumencie tym będzie szerzej mowa w dalszej części tekstu.

7 Zainteresowanych autor odsyła do pracy J. Tebinki, Polityka brytyjska wobec problemu granicy polsko-radzieckiej 1939-1945, Warszawa 1998. Na ten temat zob. również: P. Eberhardt, Polska granica wschodnia 1939-1945, Warszawa 1993; idem, Jak kształtowała się wschodnia granica PRL, „Zeszyty Historyczne" 1989 (Paryż), z. 90, s. 3-34; J. Tebinka, Sprawa polska w polityce Wielkiej Brytanii i Stanów Zjednoczonych (od Teheranu do Jałty), „Mazowieckie Studia Humanistyczne” 2004, nr 1-2, s. 137-159.

${ }^{8}$ A. Zięba, Historyk jako produkt historii, czyli o tym, jak Ludwik Bernstein przekształcił się w Lewisa Namiera, [w:] Historyk i historia. Studia dedykowane pamięci Mirosława Francicia, red. A. Walaszek, K. Zamorski, Kraków 2005, s. 154-155; J. Namier, Lewis Namier. A biography, Londyn 1971, s. 8-9, 36-37.
} 
Rodzina przenosiła się kolejno do Kobyłowłok, Nowosiółki Skałackiej i Koszyłowiec (w zaborze austriackim), gdzie nabyła majątek w powiecie zaleszczyckim (895 ha), szukając zakorzenienia w polskiej warstwie ziemiańskiej. Równocześnie Bernsteinowie byli właścicielami ziem w Popowcach (400 ha) oraz Białej (435 ha). Tak rozległe posiadłości umożliwiły, w późniejszym okresie, młodemu Ludwikowi podjęcie studiów za granicą. Jak twierdził, był wychowywany na Polaka. W domu rodzinnym mówiono po polsku. Jego nauczycielami byli ludzie związani z polską lewicą niepodległościową, w tym czasie jeszcze studenci, m.in. Edmund Weissberg, Stanisław Kot i Marian Kukiel. Wiadomo też, że jeszcze pod koniec XIX wieku (dokładnie w 1897 roku) jego rodzice oficjalnie byli wyznawcami judaizmu. Później przyjęli wiarę rzymskokatolicką, ale Ludwik odmówił chrztu. Być może wtedy też nastąpiła zmiana nazwiska rodziny na Niemirowski, choć nie ma pewności, czy obie kwestie były ze sobą w jakiś sposób powiązane. Na pewno nie było wcześniej żadnych powiązań Niemirowskich z Bernsteinami9.

Sam Ludwik dowiedział się o swoim żydowskim pochodzeniu w wieku dziewięciu lat, co podobno miało być dla niego szokiem. Potem wykorzystywał to, twierdząc, że właśnie ten moment stanowił początek jego prawdziwego odrodzenia narodowego ${ }^{10}$. Mieszkając już w Wielkiej Brytanii, zdecydowanie odciął się od kultury polskiej i zaczął działać w ruchu syjonistycznym. Pod koniec życia przeszedł z kolei na anglikanizm, za co spotkała go krytyka ze strony środowisk żydowskich $^{11}$. Niektórzy twierdzą, że to na tle konwersji na judaizm zrodził się jego konflikt z ojcem, zakończony zerwaniem więzów rodzinnych. Wydaje się to jednak nie do końca uzasadnione, zwłaszcza że sam Namier w liście skierowanym do Józefa wyraził troskę o los rodziny, jednocześnie jednak namawiając ją do opuszczenia Polski i oferując przy tym swoją pomoc ${ }^{12}$. Julia Namier [druga żona L. Namiera -

${ }^{9}$ A. Zięba, op. cit., s. 162-163, 168. Inną wersję podaje w swojej biografii Lewisa Namiera jego druga żona Julia. Pisze ona, że nie da się dokładnie ustalić, w którym momencie nastąpiła zmiana nazwiska. Twierdzi jednak, że rodzina już wcześniej posługiwała się nazwiskiem Niemirowski, a nazwisko Bernstein zostało narzucone przez zaborcę pod koniec XVIII wieku. Później w różnych dokumentach do nazwiska Bernstein dodawano także człon „vel Niemirowski”. Zob. J. Namier, op. cit., s. 3. Trzeba tu wszakże poczynić uwagę, że Julia podaje w swojej książce głównie informacje przekazane jej przez męża, a jak wiadomo zostały one w dużej mierze spreparowane przez samego Namiera. Bodziec do zaprojektowania własnej biografii przyszedł z USA pod koniec lat pięćdziesiątych XX wieku, gdzie rozpowszechniano o nim różne historie. Jak wskazuje A. Zięba, Namier miał podyktować swojej żonie życiorys od momentu swojego urodzenia do końca I wojny światowej. Powodem tej autokreacji miała być obawa, że kolejne pokolenia mogą źle ocenić jego działalność w tym okresie. Zob. A. Zięba, op. cit., s. 152. Z tego względu wszystkie informacje cytowane z książki J. Namier są obciążone w pewnym stopniu subiektywizmem Lewisa Namiera.

${ }^{10}$ Faktycznie jednak chodziło o wybicie się w ruchu syjonistycznym i ukrycie swojej ignorancji w sferze kultury żydowskiej. Zob. A. Zięba, op. cit., s. 164. Więcej na temat powiązań Namiera z ruchem syjonistycznym: N. Rose, Lewis Namier and Zionism, Oxford 1980. Recenzję tej książki zob. J. Israel, Brilliant Misfit, „History today” maj 1981, s. 57-58.

11 A. Zięba, op. cit., s. 171.

12 Na dobre relacje z ojcem mogą też wskazywać bezpośrednie zwroty do niego w liście: „Kochany Ojcze” i „Twój L. [Lewis]”. Z drugiej jednak strony mogą to być jedynie puste słowa, wynikające z uży- 
B.R.] twierdzi natomiast, że do ostatecznego rozerwania więzów łączących Lewisa z ojcem przyczynił się najbardziej Roman Dmowski. Bezpośrednim powodem miały być jego działania podczas I wojny światowej i oskarżenie wysunięte pod adresem Józefa Niemirowskiego o szpiegowanie na rzecz Wiednia. W artykule prasowym z kwietnia 1918 roku, rzekomo inspirowanym przez prezesa Komitetu Narodowego Polski, o zdradę został oskarżony również sam Lewis ${ }^{13}$.

Na niechęć Namiera do Polaków wpłynął też antysemityzm, z którym zetknął się jeszcze podczas swojego pobytu w Galicji Wschodniej. Istnieją dwie sprzeczne wersje na ten temat. Wedle pierwszej relacji przyczyną jego urazy stała się rozmowa polskich ziemian, podsłuchana przez młodego Ludwika podczas podróży pociągiem, kiedy to mieli oni naśmiewać się z pochodzenia jego ojca ${ }^{14}$. Druga wersja mówi, że Namier miał zetknąć się z antysemityzmem ze strony młodzieży narodowej podczas swoich studiów we Lwowie. Osoby te miały przypominać - według relacji Julii Namier (Lewisa Namiera?) - typ reprezentowany później przez nazistów, a ich zachowanie i głoszone idee były wynikiem działalności Dmowskiego i innych aktywistów obozu narodowodemokratycznego ${ }^{15}$. Prawdopodobnie był to jeden z powodów późniejszego zaciekłego konfliktu między Namierem a prezesem KNP w kwestii odbudowy państwa polskiego po I wojnie światowej.

Po tych przykrych dla siebie doświadczeniach Ludwik postanowił wyjechać na studia za granicę. Pod koniec 1906 roku znalazł się w Lozannie, gdzie był uczniem m.in. Vilfreda Pareto. Ponoć to tutaj miało nastąpić również jego pierwsze poważniejsze zetknięcie z ruchem syjonistycznym, z którego ideologią miał się odtąd identyfikować, jednocześnie nawiązując bliższą współpracę z tamtejszymi działaczami ${ }^{16}$. W Szwajcarii nie zagrzał jednak długo miejsca i za sprawą swojego anglofilskiego kuzyna oraz prof. Pareto zdecydował się na wyjazd do Anglii, gdzie znalazł się już rok później. Najpierw trafił do London School of Economics, a następnie do Balliol College w Oxfordzie. Tutaj jego opiekunem został Paweł Winogradow, co podobno również nie pozostało bez wpływu na jego poglądy odnośnie do Polski. Świat brytyjski miał go wchłonąć bardzo szybko. Proces ten był tak silny, że spędzone na Oxfordzie lata studiów bardzo oddaliły młodego Ludwika od polskości. Jednocześnie on sam na każdym kroku starał się podkreślać swoje przywiązanie do kraju i kultury brytyjskiej. Podczas pobytu w Balliol

wania form grzecznościowych w korespondencji. Zob. J. Pisuliński, Nieznany list brytyjskiego historyka, „Zeszyty Historyczne” 2002 (Paryż), z. 141, s. 225-232.

13 J. Namier, op. cit., s. 128-129.

14 A. Zięba, op. cit., s. 165.

15 J. Namier, op. cit., s. 60-61. W tej wizji utwierdził ją także przebywający na emigracji August Zaleski, już po śmierci Namiera w 1960 roku, opowiadając o tym, jak bardzo Dmowski był nienawidzony. Zob. ibidem, s. 129. Ta wersja również: A. Zięba, op. cit., s. 165.

16 M. Kukiel, Sir Lewis Namier, „Teki Historyczne” 1960-1961 (Londyn), t. XI, s. 259. Wersja ta jest sprzeczna z relacją przytoczoną przez Julię Namier nieco wyżej. Można wysunąć chyba przypuszczenie (biorąc pod uwagę późniejsze działania Lewisa), że w tym miejscu zniekształcił on swoją biografię, wybierając wygodniejszy dla siebie wariant. 
College zdołał ukończyć studia historyczne, zmienić obywatelstwo na brytyjskie, a nazwisko na Lewis Namier ${ }^{17}$.

Już po zakończeniu pracy w Foreign Office na stałe osiadł w Wielkiej Brytanii, gdzie pracował krótko jako przedsiębiorca, a także wykładał historię na uniwersytetach w Oxfordzie i Manchesterze. Specjalizował się w historii XVIII-wiecznej monarchii brytyjskiej, był także twórcą szkoły historycznej zwanej „namieryzmem” 18 . W swoich badaniach posługiwał się metodą psychoanalityczną, co wywoływało głosy krytyczne na temat jego pracy, m.in. ze strony A. J. P. Taylora. Na wyspach brytyjskich spotkał się także $\mathrm{z}$ niechęcią otoczenia, $\mathrm{z}$ jednej strony związaną z jego żydowskim pochodzeniem, z drugiej zaś cechami charakteru - natarczywością, egocentryzmem i chęcią całkowitego dominowania intelektualnego nad innymi. W świecie Żydów też nie do końca się odnalazł. Dość powiedzieć, że nigdy nie przyjął wyznania mojżeszowego oficjalnie. Cierpiał też na dotkliwą nerwicę i stany depresyjne, na co leczył się przez długie lata ${ }^{19}$.

\section{Działalność i poglądy Namiera w czasie I wojny światowej i konferencji paryskiej}

Kluczowym okresem dla zrozumienia postawy i poglądów Namiera na kwestię polską stanowi jego praca w Foreign Office, na stanowisku eksperta do spraw Polski i Europy Środkowo-Wschodniej. Formalnie pełnił tę funkcję od końca marca 1918 do 30 kwietnia 1920 roku, choć wiadomo, że współpracował z brytyjskim ministerstwem co najmniej od 1916 roku $^{20}$. Z czasem miał zyskać pozycję najbardziej kompetentnego specjalisty w tej dziedzinie, posiadającego rozległe kontakty w brytyjskich kołach rządowych, a nawet dostęp do premiera brytyjskiego Davida Lloyda George'a, a to za pośrednictwem jego osobistego sekretarza Philipa Kerra. Znaczenie Namiera było większe nawet niż autorytet jego formalnego szefa w Political Intelligence Department Esmé Howarda, uważanego za bardziej przychylnego Polsce ${ }^{21}$. A. Cienciała wskazuje jednak, że nie oznacza to, że odgrywał on rolę „szarej eminencji” w kwestii polskiej, a posłuch, jaki znajdował wśród polityków brytyjskich, był motywowany zbieżnością jego poglądów z koncepcjami formułowanymi wcześniej przez koła

17 J. Pajewski, Wokót sprawy polskiej. Paryż - Lozanna - Londyn 1914-1918, Poznań 1970, s. 209. Według relacji A. Toynbeego, to właśnie zmiana nazwiska miała stanowić symboliczną zmianę przynależności narodowej Namiera. Zob. M. Kukiel, op. cit., s. 259-260.

${ }_{18}$ M. Kukiel, op. cit., s. 260. Analizą dorobku naukowego Namiera zajęła się Linda Colley w książce: Lewis Namier, Londyn 1989.

19 A. Zięba, op. cit., s. 151-152, 167, 171-174.

20 A. Cienciała, Polityka brytyjska wobec odrodzenia Polski, „Zeszyty Historyczne” 1969 (Paryż), z. 16, s. 77. Wcześniej Namier służył w armii brytyjskiej, problemem była jednak jego wada wzroku, z powodu której miał zostać zwolniony ze służby. Być może jednak przyczyną jego odejścia z wojska było zainteresowanie wykazywane w stosunku do niego w Foreign Office. W każdym bądź razie miał on obiecać sobie, że nadal będzie służył swojemu krajowi z nie mniejszym wysiłkiem i pomysłowością niż żołnierze frontowi. Zob. J. Namier, op. cit., s. 116-121.

${ }^{21}$ Wśród innych ekspertów bliskich wnioskom Namiera był, również mający spore wpływy w Foreign Office, James Headlam-Morley. Zob. A. Nowak, Polska i trzy Rosje..., s. 143. 
rządowe w Londynie, jak również tradycyjnymi poglądami imperium brytyjskiego na kwestię układu politycznego w Europie Środkowo-Wschodniej22.

Głównym przedmiotem ataków Namiera przez cały okres jego pracy w Foreign Office był polski program terytorialny, sformułowany przez Romana Dmowskiego ${ }^{23}$. Wydaje się jednak, że problemem dla Namiera była również sama osoba i opcja polityczna reprezentowana przez szefa KNP, zwłaszcza że konflikt między oboma panami z czasem nasilił się i niepozbawiony był złośliwości. Ze strony Dmowskiego były to na przykład - wspomniane wyżej - oskarżenia wysuwane pod adresem Lewisa i jego ojca o działalność szpiegowską na rzecz Austro-Węgier, inspirowanie ataków prasowych przeciwko „temu małemu Żydkowi galicyjskiemu” (jak Dmowski pisał o Namierze $)^{24}$, kończąc na złośliwych żartach rozpuszczanych w brytyjskich kołach rządowych ${ }^{25}$. Także Namier zdecydowanie starał się zdyskredytować osobę Dmowskiego i cały Komitet Narodowy Polski.

Po raz pierwszy do starcia między obu panami doszło na początku 1916 roku, w związku z konferencją działaczy polskich w Lozannie. W obradach brał udział Witold Czartoryski, członek austriackiej Izby Panów. Wykorzystując ten fakt, Namier rzucił kłamliwe oskarżenie przeciw Dmowskiemu, twierdząc, że chce on wraz ze swoimi współpracownikami zmienić front i przejść na stronę państw centralnych. Ostatecznie sprawa została wyjaśniona po myśli Dmowskiego, któremu pomógł Artur Nicolson, udaremniając fałszerstwa Namiera u ówczesnego szefa Foreign Office, Edwarda Grey’a. Po tym incydencie prezes KNP odczuł, że Anglicy byli nieco zakłopotani nieprzyjemnościami, jakie stały się jego udziałem i byli mu bardziej pomocni. Nie udało się jednak usunąć Namiera ze stanowiska ${ }^{26}$. Tłumacząc się potem jednemu z wysokich urzędników Foreign Office, miał on mówić, że jego działania nie miały absolutnie charakteru osobistego i nie były wymierzone w szefa $\mathrm{KNP}^{27}$. Namier nie był tu jednak do końca szczery, zwłaszcza że na podważaniu autorytetu Dmowskiego na Zachodzie skupiał sporą część swojej uwagi. Apogeum

22 A. Cienciała, op. cit., s. 78. Rolę Namiera jako „dostarczyciela” informacji i argumentów przeciw Polsce podkreśla się również w innym miejscu: A. Cienciała, T. Komarnicki, From Versailles to Locarno. Keys to Polish Foreign Policy 1919-1925, Lawrance-Kansas 1984, s. 155-156.

${ }^{23}$ Program ten omawia w swojej książce Lech Wyszczelski. Zob. L. Wyszczelski, O Polsce $w$ Wersalu, Toruń 2008, s. 50-62. Noty delegacji polskiej w Paryżu dotyczące granicy zachodniej (z 28 lutego 1919 roku) i wschodniej Polski (z 3 marca 1919 roku) zob. Powstanie II Rzeczypospolitej. Wybór dokumentów 1866-1925, red. H. Janowska, T. Jędruszczak, Warszawa 1984, nr 251, nr 252, s. 481-488.

${ }^{24}$ R. Dmowski, Polityka polska i odbudowanie państwa, t. 1, Warszawa 1988, s. 266. Dmowski często skarżył się na duże wpływy Żydów w otoczeniu Lloyda George’a. Zob. T. Piszczkowski, Anglia a Polska 1914-1939 w świetle dokumentów brytyjskich, Londyn 1975, s. 49.

${ }^{25}$ W jednym z takich żartów Dmowski oskarżył „braci bliźniaków” - Bernsteina (Namiera) i Bronsteina (Trockiego) o bycie główną przyczyną problemów Europy Środkowo-Wschodniej. Zob. H. Bułhak, Za co Dmowskiemu należy się pomnik?, „Biuletyn Instytutu Pamięci Narodowej” 2007, nr 8-9, s. 116. Ten atak ułatwiła zapewne publiczna pochlebna wypowiedź Namiera o Trockim. Zob. J. Pajewski, op. cit., s. 211 [przypis nr 70].

26 R. Dmowski, op. cit., t. 1, s. 264-266; T. Piszczkowski, op. cit., s. 15.

27 J. Namier, op. cit., s. 125-126. 
tych działań było ujawnienie tajnego dokumentu, jaki szef KNP wysłał do Polski w maju 1917 roku, w którym opisane zostały relacje panujące w łonie państw członkowskich Ententy wraz z szeroką charakterystyką stosunku poszczególnych polityków do kwestii polskiej. Od ujawnienia tego dokumentu (w maju 1918 roku) miały znacznie pogorszyć się relacje Komitetu z rządami państw zachodnich i politykami wcześniej przychylnymi Polsce ${ }^{28}$. Taktyka Namiera polegała także na sugerowaniu, że Komitet Narodowy Polski pozbawiony jest szerszych wpływów w społeczeństwie polskim, jego rola zaś wiąże się tylko z poparciem udzielanym mu przez mocarstwa Ententy. Szczególne nasilenie tej argumentacji miało miejsce pod koniec wojny i w czasie konferencji pokojowej ${ }^{29}$.

Oprócz równolegle toczącego się konfliktu z Dmowskim, Namier sporo czasu poświęcał na wytwarzanie nieprzychylnej Polsce atmosfery wśród opinii publicznej i w kręgach rządzących Wielkiej Brytanii. Czynił to zarówno poprzez kolejne memoriały i analizy pisane na potrzeby Foreign Office, jak i szeroko zakrojoną działalność publicystyczną. Jego artykuły drukowano na łamach kilku periodyków, jednak jeden z najważniejszych tekstów znalazł się w czasopiśmie „The New Europe" w lutym 1918 roku, tuż po zawarciu traktatu brzeskiego. To tutaj właśnie szeroko wyłożył on swoje poglądy na temat kwestii polskiej i powojennego urządzenia Europy Środkowo-Wschodniej. Stwierdzał, że zawarcie układu z Ukrainą jednoznacznie pokazuje, że Polska jest tylko i wyłącznie pionkiem w grze międzynarodowej, niezależnie od głoszonej przez polityków tego kraju koncepcji utworzenia potężnego państwa polskiego, które miałoby zastąpić w powojennym porządku Rosję. Osłabienie dawnego imperium na wschodzie doprowadzić miało, zdaniem Namiera, do sytuacji, w której Polska znajdzie się pod wpływem oddziaływania swojego zachodniego sąsiada. Stąd w swojej ostatecznej konkluzji stwierdził, że Rzeczpospolita musi „poruszać się w orbicie rosyjskiej lub niemieckiej”” ${ }^{\text {. W }}$ artykule kwietniowym z kolei oskarżył Polaków o imperializm i szkodzenie interesom ukraińskim, co miało być niezgodne z ideałami Ententy. W odpowiedzi na ten właśnie artykuł Dmowski, piórem Roberta Usshera, oskarżył Namiera i jego ojca o zdradę. Wobec ostrzeżenia o możliwości obcięcia funduszy przekazywanych Polakom, lider KNP zaprzestał ataków ${ }^{31}$.

Więcej jednak o poglądach Namiera mówiły analizy przygotowywane przez niego na potrzeby Foreign Office. Już w maju 1917 roku spod jego pióra wyszedł memoriał, który odzwierciedlał argumenty, którymi posługiwał się także w późniejszym okresie. Optując za oderwaniem ziem wschodnich dawnej Rzeczypospolitej Obojga Narodów od odradzającego się państwa polskiego, pisał, że tamtejsza ludność woli każdą władzę, byleby nie była to władza polska. W opinii Namiera jedynymi Polakami na Kresach byli wielcy właściciele ziemscy („obszarnicy”), którzy dążyli

\footnotetext{
${ }^{28}$ T. Piszczkowski, op. cit., s. 51-53.

29 Ibidem, s. 50.

${ }^{30}$ Cyt. za: J. Pajewski, op. cit., s. 210.

31 J. Namier, op. cit., s. 127-129.
} 
do odzyskania dawnych majątków wraz z zamieszkującą je ludnością obcą etnicznie. Interesy te miał popierać „imperialistyczny” polski rząd. Namier wskazywał zresztą, że rewolucja rosyjska, uznająca prawo narodów do samostanowienia, wraz z rysującą się możliwością dokonania reformy rolnej na pewno zwiąże - według jego nomenklatury - Małorosjan (Ukraińców) i Białorosjan (Białorusinów) z przyszłym państwem rosyjskim. Obie te grupy uznawał on bowiem nie za oddzielne narody, ale za odgałęzienia jedynego narodu na wschodzie - rosyjskiego ${ }^{32}$. Ta postawa trzymania się przez Namiera koncepcji „adnoj Rassjii”, charakteryzowała go przez cały okres pracy w Foreign Office. Zaprzeczał przy tym, że miał jakiekolwiek sympatie dla ludności ukraińskiej ${ }^{33}$.

Ślady jego opracowań widoczne są również w okresie między zakończeniem I wojny światowej a rozpoczęciem konferencji paryskiej, kiedy władze brytyjskie pracowały nad przygotowaniem swojego oficjalnego stanowiska. Namier podjął jeszcze działania na początku listopada 1918 roku, kiedy to, tuż po wybuchu konfliktu polsko-ukraińskiego w Galicji Wschodniej, wystosował notatkę, w której oskarżał Polskę o imperializm, sugerując jednocześnie, aby „nakazano” Warszawie jak najszybsze dojście do porozumienia $\mathrm{z}$ władzami ukraińskimi. Ta właśnie notatka zainspirowała notę Londynu wystosowaną do Władysława Sobańskiego (przedstawiciela KNP w Londynie) 8 listopada $1918 \mathrm{roku}^{34}$. Jednocześnie Namier sugerował, że Wielka Brytania jest w możności dyktowania Polsce warunków, gdyż rząd warszawski nie ma żadnego oparcia $\mathrm{w}$ narodzie, a swoje istnienie zawdzięcza jedynie poparciu mocarstw Ententy ${ }^{35}$.

Z kolei w swoich memoriałach z 9 grudnia 1918 r. i 7 stycznia 1919 wyłożył także swoje poglądy na temat granicy wschodniej odrodzonej Rzeczypospolitej. Według jego koncepcji miała ona opierać się na dwóch rzekach - Bugu i Sanie. W pierwszym z opisywanych opracowań opowiadał się za budową Polski „zwartej i silnej” - pod tym określeniem rozumiał Polskę „etnograficzną”, w kształcie zbliżonym do dawnego Królestwa Kongresowego. W związku z tym postulował podzielić terytoria na wschodzie na takie, które bezsprzecznie powinny przynależeć do państwa polskiego, oraz takie, które absolutnie nie mogły być włączone w jego skład. O terenach spornych miano by decydować, w miarę możliwości, komisyjnie lub plebiscytowo. Proponowana linia graniczna miała przebiegać od dawnego punktu granicznego między Królestwem a Prusami Wschodnimi, dalej na północny wschód od Suwałk do Grodna, na południe wzdłuż Bugu, aż do styku dawnej granicy austro-węgiersko-rosyjskiej i stąd wzdłuż Sanu „do starej granicy

32 A. Cienciała, op. cit., s. 77; T. Piszczkowski, op. cit., s. 147.

33 J. Pisuliński, Nieznany list..., s. 232.

34 A. Cienciała, op. cit., s. 76. Nie zgadza się z tym poglądem M. Nowak-Kiełbikowa, pisząc, że to poglądy wyrażone przez Balfoura w październiku 1918 roku stały się podstawą do wystosowania noty z 8 listopada. Zob. M. Nowak-Kiełbikowa, Polska - Wielka Brytania w latach 1918-1923. Ksztaltowanie się stosunków politycznych, Warszawa 1975, s. 61. Prawdopodobnie oba dokumenty miały wpływ na tę notę, oba bowiem szły po linii polityki brytyjskiej, prezentowanej już podczas wojny.

35 T. Piszczkowski, op. cit., s. 62. 
galicyjsko-węgierskiej”. Ewentualne włączenie do Polski Przemyśla miało zależeć od woli mieszkającej tam ludności ${ }^{36}$. Należało też w ogóle wyłączyć jak największą grupę mniejszości z terytorium nowej Polski, gdyż zbyt zróżnicowana struktura ludnościowa kraju - argumentował Namier - musiałaby po raz kolejny doprowadzić państwo polskie do katastrofy, jaka była już jego udziałem pod koniec XVIII wieku ${ }^{37}$. W rzeczywistości liczba ludności polskiej mieszkającej na ziemiach kresowych wynosiła ponad $4 \mathrm{mln}$, obejmując prócz właścicieli ziemskich także liczne rzesze chłopów na wsiach oraz mieszczan i intelektualistów zamieszkujących w miastach na Kresach ${ }^{38}$. Stąd argument o słusznym rozgraniczeniu etnograficznym na Bugu i Sanie był z gruntu fałszywy, co nie przeszkadzało kręgom rządzącym na Zachodzie - szczególnie w Londynie - uznać go za obowiązujący, w imię własnych, swoiście pojmowanych interesów. Niestety pogląd ten przyjąl się w państwach zachodnich w dłuższej perspektywie czasu, stając się jedną z podstaw, na których oparty został mit „linii Curzona”"39.

W sprawie Galicji Wschodniej Namier nie miał początkowo sprecyzowanego stanowiska. Proponował przyłączenie jej do Ukrainy, a tym samym włączenie w skład Rosji lub też oddanie tych terenów Czechosłowacji. Należy przy tym zaznaczyć, że wschodnia część Galicji poza krótkim okresem lat 1914-1915 nigdy nie znajdowała się w granicach państwa rosyjskiego. Jak wiadomo, Namier był zapalonym czechofilem i przyjacielem Edwarda Benesza, uznaje się również, że to dzięki jego działaniom dyplomacja brytyjska przychylniejszym okiem spoglądała w stronę Pragi, aniżeli Warszawy ${ }^{40}$. W tym czasie w Foreign Office nie było jeszcze zgody w tej kwestii, ponieważ koła wojskowe forsowały koncepcję przekazania ziem wschodniogalicyjskich Polsce, jako jedynego możliwego zabezpieczenia przed rozciągnięciem się rewolucji bolszewickiej także na te terytoria. Przeciwnikiem tej opcji był szef brytyjskiego ministerstwa spraw zagranicznych Artur J. Balfour, optujący za pozostawieniem całej Galicji w rękach przyszłej Rosji. Zdaniem autora, Namier nie mając jeszcze w tym momencie pewności, jaka będzie decyzja rządu w Londynie, nie chciał jednoznacznie poprzeć żadnej opcji, starając się jednocześnie czynić wszystko, aby ziemie te nie znalazły się pod kontrolą administracji polskiej ${ }^{41}$. Po

${ }^{36}$ Za ziemię rosyjską uważał również wschodnią Chełmszczyznę, która - w jego opinii - powinna zostać przyłączona do Rosji. Zob. ibidem, s. 78.

37 Ibidem, s. 73-75.

38 Według obliczeń Piotra Eberhardta, dokonanych na podstawie spisu z 1931 roku, z uwzględnieniem przyrostu naturalnego do 1 września 1939 roku, Kresy Wschodnie zamieszkiwało 13,7 mln osób, w tym najwięcej Polaków - około 5,4 mln. Nie-Polaków było 8,3 mln, w tym największą część stanowili Ukraińcy - 4,7 mln, Białorusinów było prawie $2 \mathrm{mln}$, a Żydów około 1,3 mln. Pozostała ludność liczyła około 300 tys., a stanowili ją m.in. Niemcy, Czesi i Tatarzy. W tej grupie byli również Rosjanie, których liczebność była jednak niewiele większa niż 100 tys. osób. Zob. P. Eberhardt, Polska granica wschodnia..., s. 48-50.

${ }^{39}$ O. Halecki, Mit linii Curzona, [w:] Oskar Halecki. Historyk - Szermierz Wolności, oprac. J. Cisek, Warszawa 2009, s. 245-246.

40 A. Cienciała, op. cit., s. 78-79.

${ }^{41}$ M. Nowak-Kiełbikowa, op. cit., s. 60-61. 
przedstawieniu oficjalnego stanowiska Londynu nie miał już wątpliwości, którą wersję powinien wspierać. Mógł też być niechętny przekazaniu Galicji Wschodniej Polsce ze względu na ogólną awersję do tego kraju, ale i na podstawie własnych obserwacji tamtejszej ludności rusofilskiej. Uznał, że chciała ona przynależeć do Rosji ${ }^{22}$. W późniejszym czasie sformułował również wniosek, aby nadzór nad Galicją Wschodnią objął komisarz z ramienia Ligi Narodów ${ }^{43}$. W tym kontekście stwierdzenia Namiera, że nie miał on żadnych sympatii do ludności ukraińskiej ${ }^{44}$, wydają się być nieco nieszczere. $Z$ jednej strony może to wynikać ze zdecydowanej wrogości do Polski i preferowanego w tym wypadku wsparcia strony ukraińskiej w ich konflikcie dwustronnym, szczególnie po 25 czerwca 1919 roku, kiedy to przyznano stronie polskiej prawo do rozciągnięcia okupacji wojskowej na całe terytorium Galicji Wschodniej aż po rzekę Zbrucz. Działania Namiera szły tu w stronę zapewnienia Ukraińcom jak najszerszej autonomii, przeciwdziałania polskiej akcji kolonizacyjnej, a także wyznaczenia możliwie krótkiego terminu do zakończenia działalności polskiej administracji okupacyjnej. Poglądów tych nie zmienił nawet pod wpływem informacji o spaleniu jego domu rodzinnego przez nacjonalistycznie nastawione grupy Ukraińców. Podkreślał, że bardzo długo zachowywali oni spokój, licząc na przekazanie im władzy nad Galicją Wschodnią przez wielkie mocarstwa ${ }^{45}$.

Kontrowersyjny był również sposób, w jaki Namier przedstawiał stosunki ludnościowe panujące na dawnych Kresach południowo-wschodnich. W swoim grudniowym memoriale, powołując się na statystykę austro-węgierską z 1910 roku, zakwestionował liczbę 2 mln Polaków zamieszkujących ten obszar, wyróżniając w tej grupie: 600 tys. Żydów, którzy posługiwali się językiem polskim, 500 tys. osób wyznania rzymskokatolickiego - „mówiących po rusku, a nie po polsku” oraz 200 tys. grekokatolików, którzy „oszukańczo” zostali uznani za Polaków. Tym samym redukował liczbę Polaków do 600-700 tys. osób. Podobnie tendencyjnie przedstawił sytuację na pograniczu polsko-rosyjskim, uznając, że nie ma tam zwartych grup osadnictwa polskiego, a w swoich wywodach posługiwał się statystykami narodowościowymi rosyjskimi, pomniejszającymi odsetek ludności polskiej. Stąd też dwie największe enklawy polskie na wschód od linii etnograficznej - Lwów i Wilno powinny zostać przyłączone do przyszłej Rosji, z zagwarantowaniem jedynie autonomii kulturalnej dla mieszkającej tam ludności obcej ${ }^{46}$.

Zarysowane wyżej stanowisko i argumenty, jakimi posługiwał się Namier, są charakterystyczne dla całego okresu jego pracy w Foreign Office od zakończenia I wojny światowej. Niewątpliwie dostarczyły one polityce brytyjskiej wielu argu-

${ }^{42}$ Namier miał podobno w ogóle podzielać zdanie polskich nacjonalistów o Ukraińcach tzn. uważał, że nie ma takiego narodu, a ziemie te powinno się oddać Rosji. Zob. A. Zięba, op. cit., s. 169-170.

${ }^{43}$ T. Hunczak, Sir Lewis Namier and the struggle for Eastern Galicia, 1918-1920, „Harvard Ukrainian Studies" 1977, z. 1, s. 205.

${ }^{44}$ Tak pisał w cytowanym już liście do ojca. Zob. J. Pisuliński, Nieznany list..., s. 232.

45 Tego typu argumenty wysunął po raz pierwszy, jeszcze zanim dowiedział się, że jego rodzina przeżyła te ataki. Zob. T. Hunczak, op. cit., s. 205-210. Por. J. Namier, op. cit., s. 143-146.

${ }^{46}$ T. Piszczkowski, op. cit., s. 78-79. 
mentów natury „etnograficznej” i politycznej, jednak nie należy ich wiązać - autor zgadza się tu z opinią A. Cienciały - z przyznawaniem Namierowi istotnej roli w kształtowaniu kierunków i podstaw brytyjskiej polityki zagranicznej w kwestii pogranicza polsko-rosyjskiego i polsko-ukraińskiego. Był on tylko dostarczycielem wielu argumentów do walki z roszczeniami polskimi na konferencji pokojowej ${ }^{47}$.

\section{Prace nad wykreśleniem granicy polsko-rosyjskiej na konferencji pokojowej w Paryżu}

Do prac nad tym problemem została wyznaczona 12 lutego 1919 roku Komisja do Spraw Polskich, pod przewodnictwem Francuza Julesa Cambona, nazywana potocznie komisją Cambona. W jej skład wchodzili również przedstawiciele innych mocarstw, zazwyczaj nieprzychylni wobec roszczeń polskich na Wschodzie ${ }^{48}$. Oczywistą rzeczą jest, że starali się oni wypełniać koncepcje formułowane w kręgach rządzących swoich krajów, naciskając przede wszystkim na nieco bardziej przychylnego Polsce Cambona. Polityka francuska w największym stopniu podlegała fluktuacjom, ze względu na zmieniającą się sytuację polityczną i militarną na wschodzie kontynentu europejskiego. Stąd w momentach, gdy pojawiała się możliwość odbudowy dawnej Rosji - sukcesy odnoszone na frontach wojny domowej przez kontrrewolucyjne siły „białych” generałów lub w chwilach zagrożenia swoich interesów w Alzacji, Lotaryngii i Zagłębiu Saary - Paryż porzucał sprawę polską na pograniczu polsko-rosyjskim, skupiając swoją uwagę na bardziej istotnych dla siebie kwestiach ${ }^{49}$.

W Komisji do Spraw Polskich, dla przyspieszenia prac, powołano wkrótce tzw. podkomisję Le Ronda. Efektem jej obrad był projekt tymczasowego rozgraniczenia polsko-rosyjskiego, ogłoszony 14 kwietnia 1919 roku. Nie było w nim mowy o Galicji Wschodniej, gdzie nadal toczył się konflikt polsko-ukraiński. Raport podkomisji okazał się wybitnie niekorzystny dla Polski. Proponowano w nim oparcie wschodniej granicy państwa polskiego na Bugu, odcinając przy tym także miasta Grodno i Brześć, które, według nieco wcześniej formułowanych rozwiązań, miały znaleźć się w granicach naszego kraju. Uwzględniono także roszczenia przedstawicieli „białych” na konferencji pokojowej w stosunku do Chełmszczyzny, choć formalnie nie brali oni udziału w obradach ani nie występowali oficjalnie na równi z delegacjami innych krajów ${ }^{50}$. Rzuca to dobre światło na ich rzeczywiste

\footnotetext{
47 A. Cienciała, op. cit., s. 83.

48 Oprócz przedstawicieli państw anglosaskich przeciwny roszczeniom polskim na Wschodzie był delegat włoski della Torretta. W przeszłości sprawował on funkcję ambasadora w Rosji, a na konferencji pokojowej stał się rzecznikiem interesów tego kraju. Podczas prac w podkomisji Le Ronda w marcu 1919 roku wyraził opinię, że granice wschodnie Polski powinny odpowiadać granicom ustalonym na Kongresie Wiedeńskim, z wyłączeniem guberni chełmskiej i suwalskiej, których status jako etnicznie niejednolitych miał być rozpatrzony oddzielnie. Zob. A. Juzwenko, Stosunek „,białej” Rosji do odradzającego się państwa polskiego i jego granic, „Kwartalnik Historyczny” 1973, R. LXXX, nr 1, s. 628-629.

49 T. Piszczkowski, op. cit., s. 97; L. Wyszczelski, op. cit., s. 101.

50 Proponowana linia rozgraniczenia dochodziła tylko do wysokości Chełma. Zob. T. Piszczkowski, op. cit., s. 116-117.
} 
znaczenie w Paryżu i stosunek, jaki miały do Rosji carskiej wielkie mocarstwa. Propozycję projektu komisja Cambona przekazała następnie do sekretariatu Rady Najwyższej w końcu kwietnia 1919 roku, jednak do czasu zakończenia konferencji pokojowej sprawa ta była traktowana marginalnie. Sugerowano przy tym, aby z ostateczną decyzją zaczekać do ukonstytuowania się jakiegoś rządu rosyjskiego ${ }^{51}$. Do całej sprawy powrócono dopiero 8 grudnia 1919 roku, kiedy to Rada Najwyższa zatwierdziła proponowaną linię - przebiegającą od Grodna na północy, wzdłuż Bugu, aż do Sokala na południu - na zachód od której Polska miała prawo budować zręby swojej administracji państwowej. Jednocześnie „zastrzeżone wyraźnie” zostały prawa naszego kraju do ziem na wschód od tej linii - przypomnijmy doprowadzonej tylko do wysokości Chełma, z pretensjami do których Warszawa mogłaby wystąpić w przyszłości ${ }^{52}$. Linia z 8 grudnia 1919 roku nie miała być więc granicą polityczną polsko-rosyjską, jak uważano na Zachodzie ${ }^{53}$. W tym czasie Polska kontrolowała tereny daleko na wschód od rzeki Bug, co stało się zresztą przedmiotem ostrej krytyki ze strony Namiera, uważającego polski rząd za nieudolny i skorumpowany, jednocześnie przestrzegając przed udzielaniem pomocy państwu, które podtrzymało reżim bolszewicki w Rosji ${ }^{54}$. Była to więc wyraźna aluzja do wstrzymania ofensywy przeciw bolszewikom przez Piłsudskiego i rozpoczęcie rozmów w Mikaszewiczach ${ }^{55}$.

Znacznie trudniejsze było wypracowanie przez mocarstwa jakiegoś stanowiska w sprawie Galicji Wschodniej, ze względu na toczącą się na tych ziemiach wojnę polsko-ukraińską. Fiasko ponosiły kolejne misje alianckie, przybywające tam, aby doprowadzić do zawarcia jakiejś formy rozejmu ${ }^{56}$. Składający swój raport po jednej z takich misji gen. Joseph Barthélemy, generalnie przychylny Polsce, został zaatakowany przez premiera brytyjskiego Lloyda George’a, sprzeciwiającego się tworzeniu jakichkolwiek faits accomplis na wschodzie przez stronę polską. Rada Najwyższa postanowiła dalej starać się o zawarcie rozejmu między walczącymi stronami i wypracowanie projektu podziału wschodniej części Galicji ${ }^{57}$. Należy również dodać, że istotną częścią rywalizacji mocarstw zachodnich w Galicji Wschodniej była kwestia złóż ropy naftowej, gdzie dominację uzyskały przedsiębiorstwa francuskie. Nie podobało się to z kolei Brytyjczykom, którzy poprzez odebranie tych ziem Polsce i włączenie ich w skład Rosji chcieli zmusić rząd paryski do wznowie-

51 L. Wyszczelski, op. cit., s. 114-115.

52 Pełny tekst deklaracji: Powstanie II Rzeczypospolitej. Wybór dokumentów..., nr 267, s. 532-534.

53 O. Halecki, op. cit., s. 244.

54 T. Piszczkowski, op. cit., s. 141-142.

55 A. Nowak, Polska i trzy Rosje..., s. 378-397.

56 Wyjątek stanowiła tu misja gen. Josepha Barthélemy’ego, któremu udało się zmusić obie strony do podpisania zawieszenia broni. Zostało ono jednak bardzo szybko zerwane przez stronę ukraińską. Zob. J. Pisuliński, Nie tylko Petlura..., s. 101-113; P. Żurawski vel Grajewski, Sprawa ukraińska na konferencji pokojowej w Paryżu w roku 1919, Warszawa 1995, s. 22-25; M. Klimecki, Alianckie misje we Lwowie (listopad 1918 - luty 1919), „Studia z Dziejów Rosji i Europy Środkowo-Wschodniej” 1996, t. XXXI, s. 35-50.

57 P. Żurawski vel Grajewski, op. cit., s. 24-27; T. Piszczkowski, op. cit., s. 107-110. 
nia stosunków dyplomatycznych z państwem rosyjskim, niezależnie od tego, kto objąłby władzę na Kremlu ${ }^{58}$.

Niezdecydowanie mocarstw widoczne było również w pracach komisji Cambona. $\mathrm{Na}$ tym forum sformułowano w czerwcu 1919 roku aż pięć wariantów statusu i podziału Galicji Wschodniej. Na ogół były one niekorzystne dla Polski, gdyż rozpatrywano jedynie ewentualność, w której przyłączenie tych ziem do naszego kraju nastąpiłoby na zasadzie federacji lub $\mathrm{z}$ udzieleniem mandatu na pewien okres, po którym miałby zostać przeprowadzony plebiscyt. W tym samym dniu, 17 czerwca, zaproponowano również dwie koncepcje podziału spornego obszaru. Linia A przebiegała na zachód od Lwowa i borysławskiego zagłębia naftowego i była w przybliżeniu zgodna z rozgraniczeniem etnicznym w Galicji Wschodniej. To właśnie według tej propozycji dokonano później przedłużenia „linii Curzona” na odcinku południowym. Linia B pozostawiała natomiast Lwów i zagłębie naftowe po stronie polskiej ${ }^{59}$. Niemalże natychmiast zdecydowano jednak o oddaniu całego spornego terytorium po Zbrucz pod okupację wojskową Polski, a to ze względu na zagrożenie bolszewickie i możliwość połączenia się rewolucji rosyjskiej i węgierskiej. Jednocześnie podjęto prace nad statutem dla Galicji Wschodniej, który miał nie tylko zapewnić szeroką autonomię mieszkającej tam ludności niepolskiej, ale który - do czego najbardziej dążyli Brytyjczycy - miał obowiązywać również możliwie krótko, po czym przeprowadzono by plebiscyt $\mathrm{t}^{60}$. Wielkie mocarstwa czerpały swoją legitymację do decydowania o tych terenach $\mathrm{z}$ traktatu pokojowego zawartego z Austrią, wedle którego to na nie zostały scedowane wszystkie prawa suwerenne do ziem, znajdujących się poza granicami tego państwa po wojnie, czyli również do Galicji Wschodniej ${ }^{61}$.

Ostatecznie 21 listopada 1919 roku ogłoszono ustanowienie mandatu polskiego nad Galicją Wschodnią na okres 25 lat, pod kontrolą Ligi Narodów i z zapewnieniem swobód ludności ukraińskiej62. Wobec jednak kolejnych porażek ponoszonych przez wojska białogwardyjskie i obawie rozlania się rewolucji przez Bałkany na całą Europę dokonano rewizji tej decyzji, zawieszając wykonanie mandatu, co oznaczało przywrócenie okupacji wojskowej i przyznanie Polsce praw do całej wschodniej części Galicji aż po Zbrucz na czas nieokreślony ${ }^{63}$. Cała sprawa miała powrócić na forum międzynarodowe, a to za sprawą noty z 11 lipca 1920 roku i wpisanym w nią odcinkiem południowym „linii Curzona”, łudząco podobnym do projektu linii A z czerwca 1919 roku.

58 Z. Zaks, Walka dyplomatyczna o naftę wschodniogalicyjską 1918-1923, [w:] Z dziejów stosunków polsko-radzieckich. Studia i materiały, t. 4, red. T. Cieślak, Warszawa 1969, s. 37-60.

59 Szczegółowy przebieg rozgraniczenia wraz z opisem terytoriów spornych przybliża w swoim artykule Henryk Batowski. Zob. H. Batowski, Linia Curzona a była Galicja Wschodnia, [w:] idem, Z polityki międzynarodowej XX wieku. Wybór studiów z lat 1930-1975, Kraków 1979, s. 188-189.

60 T. Piszczkowski, op. cit., s. 113.

61 Powstanie II Rzeczpospolitej. Wybór dokumentów..., nr 263, s. 517.

62 M. Nowak-Kiełbikowa, op. cit., s. 142-155; P. Żurawski vel Grajewski, op. cit., s. 39-42.

63 Powstanie II Rzeczypospolitej. Wybór dokumentów..., nr 269, s. 535. 
Do końca 1919 roku nie podjęto już żadnych innych decyzji czy zmian w interesującej nas kwestii. Jak wiemy, w kolejnym roku Piłsudski podjął próbę dokonania decydującego rozstrzygnięcia na wschodzie, rozpoczynając w końcu kwietnia ofensywę na Ukrainie. Okazało się jednak, że bolszewicy potrafili poradzić sobie w tej sytuacji, wycofując się na wschód i pozwalając zająć Polakom ogromne obszary praktycznie bez walki. W dalszym okresie wypadki wojenne potoczyły się już niekorzystnie dla Polski. Po przygotowaniu przeciwnatarcia, wojska Armii Czerwonej zaczęły spychać oddziały polskie coraz bardziej na zachód. W początkach sierpnia 1920 roku zagrożona została Warszawa ${ }^{64}$.

Polacy, świadomi swojej trudnej sytuacji, postanowili podjąć rozmowy z przedstawicielami wielkich mocarstw, przebywającymi wtedy na konferencji w Spa. Lloyd George zamierzał wykorzystać zaistniałe warunki, nakładając na Polskę upokarzające zobowiązania, które w dniu 10 lipca 1920 roku przyjął premier Władysław Grabski. W umowie żądano od Polski m.in. wycofania swoich wojsk na linię z 8 grudnia 1919 roku i oddanie Wilna Litwie, zdania się na decyzje mocarstw w sprawie konfliktów z innymi sąsiadami (w kwestii Gdańska i Śląska Cieszyńskiego) oraz zwołania międzynarodowej konferencji, w której mieliby też wziąć udział przedstawiciele Galicji Wschodniej. Co do podziału tego ostatniego terytorium uzgodniono tylko, że wojska polskie i bolszewickie zatrzymają się na linii osiągniętej w dniu podpisania rozejmu, z cofnięciem się o $10 \mathrm{~km}$ przez każdą ze stron. Jednocześnie odmówiono Polsce wsparcia zbrojnego. Francuzi natomiast zajęli pozycję wyczekującą, całkowicie oddając sprawę pośrednictwa między Polakami a bolszewikami w ręce brytyjskie ${ }^{65}$.

Następnego dnia stronie sowieckiej wysłano ze Spa notę z propozycją zawarcia rozejmu. Francuzi odmówili swojego podpisu, nie wiadomo również, czy notę podpisał sam Curzon, czy tylko została ona wysłana w jego imieniu. Treść tego dokumentu różniła się od warunków przedstawionych i zaakceptowanych przez Grabskiego, właśnie w opisie proponowanej linii rozejmowej.

\section{Problem przebiegu i autorstwa „linii Curzona”}

Kwestia ta do dzisiaj budzi największe kontrowersje zarówno wśród historyków-profesjonalistów, jak i sympatyków tej dziedziny nauki. Problemem jest przede wszystkim przebieg linii na odcinku w Galicji Wschodniej, łudząco podobny do linii A z 1919 roku, ale - co ważniejsze - projekt ten nie został oficjalnie przedstawiony przez stronę brytyjską premierowi Grabskiemu przed wysłaniem noty. Grabski, podpisując ciężkie warunki narzucone przez Londyn, nie zgadzał się na odcięcie wschodniej części Galicji od Polski. Jak się jednak okazało następnego dnia, tj. 11 lipca 1920 roku, w nocie wysłanej stronie sowieckiej znajdował się ustęp: „(...) na zachód od

${ }^{64} \mathrm{Na}$ temat sojuszu polsko-ukraińskiego z kwietnia 1920 roku i jego genezy zob. S. Szajdak, Polsko-ukraiński sojusz polityczno-wojskowy w 1920 roku, Warszawa 2005; Polska i Ukraina - sojusz 1920 roku i jego następstwa, red. Z. Karpus, W. Rezmer, E. Wiszka, Toruń 1997.

${ }_{65}$ Tekst umowy z Grabskim z 10 lipca 1920 zob. Powstanie II Rzeczypospolitej. Wybór dokumentów..., nr 288, s. 561-562. O postawie Francji i Wielkiej Brytanii: M. Nowak-Kiełbikowa, op. cit., s. 211-215. 
Rawy Ruskiej, na wschód od Przemyśla do Karpat"66, który oznaczał odcięcie Lwowa i zagłębia naftowego od Polski, o którym strona polska nic nie wiedziała i na który nie wyraziła zgody. Spróbujmy przyjrzeć się bliżej temu problemowi.

Nota została wysłana ze Spa w Belgii, gdzie przedstawiciele mocarstw zebrali się, aby dyskutować nad kwestią powojennych reparacji ze strony Niemiec. Pośrednikiem w jej przekazaniu do Moskwy był niejaki Leslie, brytyjski przedstawiciel w Estonii. O wysłaniu noty zostali poinformowani także poseł brytyjski Rumbold w Warszawie, sekretarz skarbu Artur Bonar Law i lord Hardinge w Londynie. Telegram oznaczony był numerem 38, podano miejsce i datę wysłania: „Spa, July 11, 1920”. I komentarz w kopii noty wysłanej do Londynu: „Following sent to Reveal to-day, for Chicherin, Moscow" [Poniższe wysłano do ukazania dziś, dla Cziczerina, Moskwa $]^{67}$. Potwierdzają to oficjalnie wydane dokumenty ${ }^{68}$. Dlatego dziwna i nieznajdująca potwierdzenia nigdzie indziej jest wersja przytoczona w książce Stanisława Żochowskiego, mówiąca o wysłaniu dwóch not - jednej ze Spa, a drugiej z siedziby Foreign Office ${ }^{69}$.

Autorstwo „linii Curzona” przypisuje się najczęściej opisywanej tutaj szeroko postaci Lewisa Namiera. Pewność w tej kwestii wyraził Tadeusz Piszczkowski, który w komentarzu do memorandów Namiera z przełomu 1918/1919 roku, dotyczących wyznaczenia polskiej granicy na wschodzie, pisze: „(..) była to więc przyszła «linia Curzona»"70. Przypisuje mu zatem przynajmniej koncepcyjne autorstwo tego projektu. Opinię, że autorem odcinka „linii Curzona” w Galicji Wschodniej był Namier, wyraził też Tomasz Wituch ${ }^{71}$. Podobne przypuszczenia wysunęli także m.in. Henryk Batowski ${ }^{72}$ i Aleksander Wasilewski ${ }^{73}$. Problem w tym, że Namier nie był już wtedy pracownikiem Foreign Office, ponieważ swoje obowiązki, jak wskazano wyżej, zakończył z dniem 30 kwietnia 1920 roku $^{74}$. Formalna decyzja o jego rezygnacji

${ }^{66}$ Pełny przebieg linii rozejmowej umieszczony w nocie z 11 lipca 1920 roku przedstawiał się następująco: (od północy) Grodno - Wałowka - Niemirów - Brześć Litewski - Dorohusk - Ustiług, na wschód od Hrubieszowa, przez Kryłow i dalej na zachód od Rawy Ruskiej, na wschód od Przemyśla do Karpat. Zob. Powstanie II Rzeczypospolitej..., nr 289, s. 562.

67 T. Piszczkowski, op. cit., s. 158.

${ }^{68}$ Powstanie II Rzeczypospolitej. Wybór dokumentów..., nr 289, s. 562-563.

69 S. Żochowski, Brytyjska polityka wobec Polski 1916-1948, Londyn 1979, s. 44. Prawdopodobnie Żochowskiemu chodzi tu o kopię noty wysłaną do Londynu.

70 T. Piszczkowski, op. cit., s. 75.

${ }^{71}$ Opinię taką wyraził w przypisie do opracowanej przez siebie i cytowanej już tutaj pracy. Zob. R. Dmowski, op. cit., t. 2, s. 174.

${ }^{72}$ Batowski w swoim komentarzu umieścił opinię, że „istnieje duże prawdopodobieństwo, że «linia Curzona» była dziełem ówczesnego eksperta Foreign Office, L. B. Namiera (rodem z Polski)”. Zob. H. Batowski, Między dwiema wojnami..., s. 407.

73 A. Wasilewski, Granica lorda Curzona. Polska granica wschodnia od Wersalu do Schengen (traktaty, umowy, przejścia graniczne, podróżni, wizy), Toruń 2003, s. 10 [przypis nr 4]. Wasilewski powołuje się przy tym na książkę H. Nicolsona, Curzon: the last phase. A study in post-war diplomacy, Londyn 1934. Problem w tym, że na wskazanej przez niego stronie nie ma żadnej informacji na ten temat. Zob. H. Nicolson, op. cit., s. 204. Warto dodać, że nazwisko Namiera nie pada w książce ani razu.

74 A. Cienciała, op. cit., s. 77. 
miała wejść w życie 1 maja 1920 roku, jednak - jak pisał do swojego przyjaciela postanowił on wcześniej wyjechać do Oxfordu, gdzie otrzymał posadę wykładowcy. Ostatecznie opuścił Londyn już 23 kwietnia ${ }^{75}$. Na podstawie tych faktów (i niechęci Namiera do F.O., o czym dalej) można stwierdzić, że Namiera nie było w lipcu 1920 roku w Spa i na pewno nie on umieścił dodatek w nocie Curzona ${ }^{76}$. Nie ma pełnej listy doradców, jakich Lloyd George zabrał ze sobą do Belgii. Wiadomo, że byli tam, oprócz premiera, lord Curzon, Philip Kerr, Harold Nicolson, Edward Hallet Carr, Eyre Crowe, Headlam-Morley „i kilku innych"77. Nicolson w swoim dziele dotyczącym dyplomacji brytyjskiej po I wojnie światowej podaje w ogóle informację, że Curzon w rozmowie z Grabskim 10 lipca wyraził opinię, że Polacy nadużyli swojej pozycji, wchodząc na tereny ukraińskie i rosyjskie, i zalecił im wycofanie się na zachód, na „legitymizowaną granicę” [legitimate frontier]. Na pytanie, gdzie ona przebiega, odpowiedział, że przez Grodno do Białegostoku, Brześcia Litewskiego i Przemyśla do Karpat. Według tej opinii, strona polska była poinformowana o przebiegu linii rozejmowej w Galicji Wschodniej, która znalazła się potem w propozycji wysłanej Sowietom $[!]^{78}$. Z drugiej strony rodzi się pytanie, czy Nicolson celowo zataił późniejszą zmianę w nocie, czy rzeczywiście o niej nie wiedział. Przyjęcie tej drugiej wersji sugeruje, że do redakcji i wysłania noty były upoważnione tylko nieliczne osoby, spośród wszystkich przebywających w Spa. Wykluczone jest także, żeby sprzeczność w nocie była wynikiem błędu jakiegoś brytyjskiego urzędnika. Na tę wersję wskazuje Tytus Komarnicki, powołując się na opinię Witolda Sworakowskiego ${ }^{79}$. Zaprzecza jej jednak zachowanie premiera Lloyda George'a w pierwszych dniach po wysłaniu noty. Zalecał on jak najdłuższe zachowanie umowy z 10 lipca i noty w tajemnicy, nakazując przy tym szczególną dyskrecję odnośnie do odpowiedzi Sowietom z 11 lipca. Bez cienia wątpliwości można chyba uznać, że Lloyd George wiedział o dokonanych zmianach, prawdopodobnie wprowadził je sam lub razem ze swoim osobistym sekretarzem Philipem Kerrem ${ }^{80}$. Sformułowano zresztą opinię, że „linia Curzona” powinna się tak naprawdę nazywać „linią Kerra” ${ }^{81}$. Rolę sekretarza w tej sprawie (a także całej polityce brytyjskiej wobec Polski) podkreślają Andrzej

75 J. Namier, op. cit., s. 152.

${ }^{76}$ Wersję, że Namier był wtedy pracownikiem Foreign Office, jako ostatni chyba powtarza Norman Davies w swojej książce Powstanie '44, Kraków 2006, s. 201. Dodaje on również, że podobno Namier miał po latach chwalić się, że to on jest faktycznym twórcą „linii Curzona”. Zob. ibidem. Tego rodzaju opinie najczęściej spotkać można w Internecie, są one jednak zdecydowanie nieprawdziwe, a często też pisane pod z góry ustaloną tezę. Dotyczy to też najbardziej popularnych portali internetowych, nie wspominając już o innych, tworzonych $\mathrm{z}$ wyraźnym nachyleniem ideologicznym.

77 T. Piszczkowski, op. cit., s. 157.

${ }^{78}$ H. Nicolson, op. cit., s. 204.

79 T. Komarnicki, Rebirth of the Polish Republic. A study in the diplomatic history of Europe, 1914-1920, Londyn 1957, s. 612.

${ }^{80}$ Faktyczny szef Foreign Office lord Curzon został odsunięty od prac nad notą. Zob. M. Nowak-Kiełbikowa, op. cit., s. 202, 215-218.

${ }^{81}$ Taką opinię wyraził R. H. Ullman. Zob. J. Tebinka, Polityka brytyjska wobec problemu..., s. 20 [przypis nr 40]. 
Nowak $^{82}$, Tomasz Wituch ${ }^{83}$ oraz Maria Nowak-Kiełbikowa ${ }^{84}$. Można przypuścić, że - nie różniąc się w swoich poglądach na temat „słusznego" rozgraniczenia w Galicji Wschodniej - obaj panowie uzgodnili między sobą umieszczenie w nocie znanej już formuły. Jednocześnie w tekście powstawała sprzeczność, wprowadzając bowiem zapis o linii rozejmowej w Galicji Wschodniej, pozostawiono klauzulę mówiącą o zatrzymaniu wojsk na linii frontu w dniu zawarcia rozejmu, bez części mówiącej o cofnięciu swoich wojsk o $10 \mathrm{~km}^{85}$. Jest to więc oczywiste niedopatrzenie. Mówiący po polsku i angielsku Namier chyba nie popełniłby takiej pomyłki. W tej sytuacji musiał to być któryś z polityków brytyjskich.

Tadeusz Piszczkowski wskazuje, że autorem dodatku musiał być ktoś zaznajomiony z geografią Polski, a przede wszystkim Galicji Wschodniej. Przywołuje też opinię Tytusa Komarnickiego, że umieszczenia dodatku w nocie mógł dokonać „(...) ktoś o złej woli w otoczeniu Curzona, kto nadużył jego zaufania”" ${ }^{86}$. Pierwsza sugestia wydaje się jak najbardziej na miejscu, w końcu Namier pochodził z Galicji, tam mieszkała także jego rodzina. Musiał więc znać te tereny. Nie on jednak był autorem przedłużenia linii w Galicji Wschodniej. Wracając do przywoływanych wyżej memorandów, widać wyraźnie, że Namier postulował w nich oddanie Galicji Wschodniej albo Rosji, albo Czechosłowacji. Nie będąc jeszcze w tym momencie pewnym, która opcja przeważy, nie chciał forsować wersji sprzecznej z oficjalną linią rządu Wielkiej Brytanii. Świadczyć może o tym chociażby fragment przywoływanego kilkakrotnie listu do ojca, w którym podkreśla on swoją rolę jako angielskiego urzędnika i pisze o Anglii jako o „swoim kraju”"87.

Tak więc to brytyjski premier Lloyd George był architektem, „koncepcyjnym autorem" projektu linii granicznej na wschodzie, nazwanej potem od nazwiska lorda Curzona ${ }^{88}$. Nie znał on jednak zupełnie geografii Europy Wschodniej. Poglądy Namiera zgodne były oczywiście ze stanowiskiem brytyjskim, zakładającym budowę małej, „etnograficznej” Polski, a mogły one wynikać zarówno ze złych doświadczeń z lat młodości spędzonych w Galicji, jak i przywiązania do swojej nowej ojczyzny oraz chęci dobrego wypełnienia obowiązków brytyjskiego urzędnika. Wydaje się, że za uzasadnione można uznać jedynie, że to Namier (jeszcze w okresie swojej pracy dla F.O.) wyrysował na mapie linię graniczną dla Polski po myśli brytyjskich polityków, zarówno na odcinku północnym, jak i dodatek w Galicji Wschodniej: „(...) na zachód od Rawy Ruskiej, na wschód od Przemyśla do Karpat”. Mógł być więc jedynie

82 A. Nowak, Porozumienie imperiów: jego beneficjenci i ofiary. O tzw. nocie Curzona $z 11$ lipca 1920 r. i jej (możliwych) konsekwencjach, [w:] idem, Ofiary, imperia i historycy. Studium przypadków(od XVIII do XXI wieku), Kraków 2009, s. 116-117.

${ }^{83}$ R. Dmowski, op. cit., t. 2, s. 61-62.

${ }^{84}$ M. Nowak-Kiełbikowa, op. cit., s. 93.

85 Ibidem, s. 218.

86 T. Piszczkowski, op. cit., s. 158-159.

87 J. Pisuliński, Nieznany list..., s. 230-231.

${ }^{88}$ W literaturze naukowej nazwa „linia Curzona” pojawiła się po raz pierwszy w artykule Roberta Lorda na łamach amerykańskiego periodyku „Foreign Affairs” w czerwcu 1923 roku. Zob. J. R. Hooker, Lord Curzon and the „Curzon Line”, ,The Journal of Modern History” 1958, vol. 30, nr 2, s. 138. 
„autorem-wykonawcą. Namier był potrzebny Brytyjczykom tylko dlatego, że dobrze znał tereny Europy Środkowo-Wschodniej i w tym kontekście mógł być dostarczycielem wielu argumentów i informacji przeciw Polsce. W przypadku, gdyby głosił odmienne opinie, zostałby zmarginalizowany, polityką brytyjską kierował bowiem osobiście Lloyd George, nie zważając na nikogo przy podejmowaniu decyzji. O tym jak mało Namier znaczył dla Brytyjczyków świadczy także fakt, że nie umieszczono jego nazwiska na honorowej liście polityków i urzędników imperium brytyjskiego, pracujących nad ustaleniem pokoju, opublikowanej w „The Times” 31 marca 1920 roku. Jego przyjaciele, m.in. James Headlam-Morley i William Tyrrell, zostali wymienieni. To tylko pogłębiło jego niezadowolenie, wyrażane również odnośnie do kwestii tymczasowości rozstrzygnięć na wschodzie Europy, i sprawiło, że złożył rezygnację ${ }^{89}$.

Cel wysłania noty, wedle naświetlonych tu pokrótce poglądów panujących w kręgach rządowych Wielkiej Brytanii, wydaje się zrozumiały. Był to wyraz konsekwencji polityków brytyjskich, którzy wielokrotnie, od końca 1918 roku i przez kolejne kilka lat, dawali jasno do zrozumienia, że nie uznają włączenia ziem kresowych w granice Polski. W Londynie ciągle aktualna była polityka utrzymywania równowagi sił na kontynencie europejskim, najlepiej w wydaniu po $1815 \mathrm{roku}$, kiedy to w Europie Środkowo-Wschodniej istniało tylko kilka państw. Wspólna granica niemiecko-rosyjska była korzystna dla Wielkiej Brytanii, gdyż dzięki temu oba te państwa szachowały się wzajemnie, co odciągało ich uwagę od zamorskich posiadłości Albionu i pozwalało na dalszą, nieskrępowaną penetrację ich bogactw. Stąd Polska - jeśli miała w ogóle istnieć - powinna być państwem małym, aby nie przeszkadzać w rywalizacji tych dwóch mocarstw europejskich. Zresztą ziemie na wschód od Łaby tak naprawdę nigdy bliżej nie interesowały polityków brytyjskich, którzy koncentrowali się przede wszystkim na zabezpieczeniu południowego wybrzeża kanału La Manche. Tych zasad nie mogło zmienić nawet ustanowienie po I wojnie światowej Ligi Narodów ${ }^{90}$.

Drugim motywem postępowania premiera brytyjskiego były problemy gospodarcze imperium po wojnie, a przede wszystkim brak ogromnego rynku zbytu w ogarniętej wojną domową Rosji. Lloyd George swoimi ustępstwami chciał pozyskać bolszewików do wznowienia prowadzonych z przerwami, od wiosny $1920 \mathrm{roku}$, rokowań handlowych. Nie doceniał jednak czynnika ideologii komunistycznej i dążenia bolszewików do wywołania światowej rewolucji. Stwierdził nawet, że „ta sprawa [najazd na Polskę] nie ma nic wspólnego z komunizmem"91. Sam Curzon napisał jeszcze w 1918 roku o Lloydzie George’u, że „on sam jest trochę bolszewikiem”92.

${ }^{89}$ J. Namier, op. cit., s. 147-148. Z tymi informacjami Autor niniejszego tekstu nie spotkał się dotychczas w żadnym polskim opracowaniu. Zrozumiałe jest, że z pewnych względów mogą być one nie do końca obiektywne, jednak dużo mówią o samym Namierze. Wydaje się, że dyktując swojej żonie te zdania, po latach musiał być nadal rozgoryczony takim potraktowaniem go przez zwierzchnictwo Foreign Office.

90 A. Cienciała, op. cit., s. 89-90.

91 A. Nowak, Porozumienie imperiów..., s. 141.

92 S. Żochowski, op. cit., s. 43. 
Moskwa zdziwiona była tak szerokimi ustępstwami zawartymi w nocie Curzona, szczególnie w kwestii przyznania Galicji Wschodniej. Cziczerin, oceniając propozycje zawarte $\mathrm{w}$ dokumencie z 11 lipca, sugerował, żeby nie włączać tego obszaru do państwa sowieckiego, bo mogłoby to wywołać negatywne reperkusje ze strony Londynu wobec Leonida Krasina, delegata na rozmowy handlowe w stolicy Wielkiej Brytanii. Zwrócił tutaj przede wszystkim uwagę na złoża ropy naftowej w zagłębiu borysławskim, które miały być, według niego, w centrum zainteresowania Londynu ${ }^{93}$. Oznacza to, że w Politbiurze nie brano w ogóle pod uwagę możliwości, że Wielka Brytania może z własnej woli oddawać Rosji obszary bogate w surowce mineralne.

Z linią zawartą w nocie z 11 lipca 1920 roku wiąże się jeszcze jeden epizod. Otóż istnieje anegdota opowiadająca o dniu, w którym dyskutowano przebieg linii rozejmowej. Pracowano bardzo intensywnie, zbliżała się już pora obiadu, ale nadal nikt nie wiedział, jak powinna zostać wytyczona na mapie. W związku z tym Curzon przyniósł mapę, na której czerwoną linią wyrysowane było rozgraniczenie i projekt ten pospiesznie uchwalono. Stąd „linię Curzona” określono również mianem „linii lunchowej”. Sekretarka E. Halleta Carra, opowiadająca tę historię polskiemu pracownikowi MSZ, stwierdziła, że dyplomacja Wielkiej Brytanii właśnie tak załatwia sprawy międzynarodowe. Co prawda, relacja ta niezgodna jest $\mathrm{z}$ faktami, rzuca jednak dobre światło na postępowanie polityków i ekspertów brytyjskich w sprawach Polski oraz całej Europy Środkowo-Wschodniej ${ }^{94}$.

\section{Zakończenie}

Ostatecznie kwestia „linii Curzona”, dzięki zwycięstwu odniesionemu w bitwie warszawskiej i odparciu bolszewików daleko na wschód, straciła całkowicie swoje znaczenie. Znów jednak posypały się oskarżenia pod adresem Warszawy o imperializm i nieliczenie się z opinią wielkich mocarstw. Polacy samodzielnie porozumieli się z Sowietami, ustanawiając nową linię graniczną na mocy traktatu podpisanego w Rydze w marcu 1921 roku. „Linia Curzona” całkowicie zniknęła z polityki międzynarodowej na prawie 20 lat. Tuż po wybuchu II wojny światowej Brytyjczycy ponownie wyciągnęli ją $\mathrm{z}$ archiwum, a pomysł oddania Kresów Wschodnich pod panowanie Związku Radzieckiego znów zaczął zyskiwać wielu zwolenników ${ }^{95}$.

I tym razem kwestia przebiegu „linii Curzona” wywołała sporo kontrowersji. Debatujący podczas konferencji w Teheranie, na przełomie listopada i grudnia 1943 roku, przedstawiciele Wielkiej Trójki wiele ze swoich rozmów poświęcili Polsce, w tym kwestii granicy polsko-radzieckiej. Ówczesny szef Foreign Office Anthony Eden usiłował przekonać Stalina, że przebieg „linii Curzona” w Galicji Wschodniej nigdy nie został ostatecznie ustalony. Sowieci jednak, dysponując notą z 11 lipca 1920 roku, wymienione w niej miejscowości nanieśli na mapę i okazało się, że wschodnia część Galicji znajdowała się po stronie radzieckiej. Eden próbo-

\footnotetext{
93 A. Nowak, Porozumienie imperiów..., s. 120.

94 A. Wasilewski, op. cit., s. 9-11.

95 J. Tebinka, Polityka brytyjska wobec problemu..., s. 76-90.
} 
wał zwrócić jeszcze uwagę na nieścisłość w nocie, mówiącą o zatrzymaniu wojsk obu stron na linii osiągniętej w dniu zawarcia rozejmu, lecz cała sprawa upadła wobec postawy premiera brytyjskiego Winstona Churchilla, który stwierdził, że nie będzie podnosił lamentu $\mathrm{z}$ powodu Lwowa ${ }^{96}$. Do końca wojny przedstawiciele wielkich mocarstw trzymali się już tego projektu, niezależnie od pewnych inicjatyw wysuwanych w kręgach eksperckich państw zachodnich koalicji ${ }^{97}$. Przyjęcie „linii Curzona" jako podstawy wschodniej granicy Polski zostało ostatecznie przesądzone $\mathrm{w}$ trakcie konferencji w Jałcie w lutym 1945 roku $^{98}$.

Wróćmy jednak do kwestii najbardziej nas tu interesującej, a mianowicie działań Lewisa Namiera. Jasne jest, że w trakcie wojny i konferencji pokojowej starał się on jak najbardziej przysłużyć swojej nowej ojczyźnie, produkując ogromną ilość rozmaitych memorandów, opracowań, not i publicystyki, w których konsekwentnie występował przeciwko roszczeniom strony polskiej. Jego argumenty rzeczywiście znalazły szeroki oddźwięk w kręgach rządzących imperium brytyjskiego - w końcu, kto mógł lepiej znać się na stosunkach panujących na tych ziemiach, jeśli nie osoba pochodząca z polsko-rosyjskiego pogranicza. Autorowi nie wydaje się jednak, żeby wpływy Namiera sięgały tak daleko, jak dość często uważa się w polskiej historiografii. On sam zresztą dostrzegł, że Polacy budują fałszywy mit Namiera, pisząc do ojca: „(...) przecież wprost humorystyczne, jaką sobie o mnie ubrdali legendę"99. Faktycznie był on jedynie dostarczycielem wygodnych argumentów o charakterze etnograficznym i politycznym. Jak daleko Brytyjczycy nie liczyli się z jego osobą, udowodnił sam Namier, odchodząc z Foreign Office, obrażony za zlekceważenie jego oddania stronie brytyjskiej.

Nieprawdziwe wydają się również interpretacje mówiące, że to on był autorem koncepcji „linii Curzona”. Według uznania autora tekstu, mogła mu przypaść w udziale jedynie rola osoby, która wyrysowała tę linię na mapie. Później, według tego projektu, Brytyjczycy nieudolnie zmienili treść noty wysłanej do Moskwy, licząc na skarcenie Polski za samowolne poczynania we wschodniej części Starego Kontynentu i próby realizacji własnych koncepcji politycznych. Z pewnością nikt w tym czasie nie mógł zdawać sobie sprawy, jak wielką rolę dokument ten odegra ponownie w czasie kolejnego światowego konfliktu.

Lewis Namier, the problem of "Curzon line" and establishing of Polish eastern border after World War I

The article discusses the work of Lewis Namier (1888-1960) and his participation in establishing the Polish Eastern border after World War I. Lewis Namier, who was born as Ludwik Bernstein,

96 P. Eberhardt, Polska granica wschodnia..., s. 110-111.

97 Szerzej zob. J. Tebinka, Brytyjskie memoranda w 1944 r. w sprawie zmian linii Curzona, „Dzieje Najnowsze" 1997, nr 1, s. 149-166. Do artykułu dołączone zostały teksty obu memorandów.

${ }^{98}$ J. Tebinka, Polityka brytyjska wobec problemu..., s. 396; Teheran - Jalta - Poczdam. Dokumenty z konferencji szefów rządów trzech wielkich mocarstw, wstęp i oprac. W. T. Kowalski, Warszawa 1972, s. 206-208.

99 J. Pisuliński, Nieznany list..., s. 231. 
became a British subject after emigration from Russian Poland and started working for Foreign Office. He was considered to be one of the biggest enemies of newly independent Poland and its claims for the lands in the East of Europe, manipulating facts and giving arguments to the British government against the Polish delegation to Versailles Peace Conference. His name is also connected with the project of the so-called "Curzon line" - the line of armistice between Poland and Bolshevik Russia in the war of 1920. According to the author, Namier did not change this proposition by detaching the city of Lviv and the lands around it from Poland, although this opinion is widespread in the Polish historiography. In the article author is also referring to the other theories of the authorship of the line of July 11th 1920 and its naming, because the name "Curzon line" seems to be problematic, in spite of the fact that it has entered into the Polish historiography.

\section{Льюис Нэмир а вопрос о „линии Керзона" и формирование польской восточной границы после I мировой войны}

Целью статьи является приблизить деятельность Льюиса Нэмира (Людвика Бернстейна, 1888-1960), эксперта в британском Форин-офис во время I мировой войны и Парижской (Версальской) конференции, в вопросе установления польской восточной границы. Нэмир, родом из Польши, был решительным противником выдвижения границ этого государства далеко на восток, поэтому во всей своей деятельности он последовательно выступал против всех польских политиков стремящихся вернуть Восточные Кресы, неоднократно манипулируя фактами и прибегая к закулисным маневрам. С ним очень часто ассоциируется проблема тн. „,линии Керзона” от 11 июля 1920 г. - проекта линии перемирия во время войны между Польшей и большевистской Россией. В статье автор пытается доказать, что Нэмир не являлся автором подделки в этом проекте, хотя довольно часто можно встретится с таким мнением в польской историографии, которая приписывает ему - немного впрок - огромное влияние и значение в британской политике. Деятельность Нэмира обсуждалась на более широком фоне правил и направлений действий политики Лондона в вопросе о польской восточной границе. В статье был также сделан обзор отдельных предложений, относящихся к проблеме авторства линии от 11 июля 1920 г. а также номенклатуры, так как название „линия Керзона” кажется довольно проблематичным, несмотря на то, что уже насовсем оно вошло в польскую историографию. 